\title{
Histopathological alterations in the gill, liver and brain of cyprinus carpio on exposure to quinalphos
}

\author{
Ramesh Raju Chamarthi ${ }^{1, *}$, Manjunatha Bangeppagari², Jaffer Mohiddin Gooty ${ }^{2}$, \\ Srinivasulu Mandala ${ }^{2}$, Juan Ortiz Tirado ${ }^{2}$, Shambanagouda R. Marigoudar ${ }^{3}$ \\ ${ }^{1}$ Department of Zoology, Sri Krishnadevaraya University, Anantapur - 515003, Andhra Pradesh, India \\ ${ }^{2}$ Universidad de las Fuezas Armada (ESPE), Sangolqui, Quito, Ecuador, South America, POBOX: 171-5-231B \\ ${ }^{3}$ Integrated Coastal and Marine Area Management-Project Directorate, Ministry of Earth Sciences, Government of India, Pallikaranai, \\ Chennai - 600100
}

\section{Email addresses:}

rameshraju.phd@gmail.com (R. R. Chamarthi), manjubhargav2010@gmail.com (M. Bangeppagari), jgooty@espe.edu.ec (J. M. Gooty), mandalasrinivasulu@yahoo.in (S. Mandala), jcortiz@espe.edu.ec (J. O. Tirado), srmarigoudar@icmam.gov.in (S. R. Marigoudar)

\section{To cite this article:}

Ramesh Raju Chamarthi, Manjunatha Bangeppagari, Jaffer Mohiddin Gooty, Srinivasulu Mandala, Juan Ortiz Tirado, Shambanagouda R. Marigoudar. Histopathological Alterations in the Gill, Liver and Brain of Cyprinus Carpio on Exposure to Quinalphos. American Journal of Life Sciences. Vol. 2, No. 4, 2014, pp. 211-216. doi: 10.11648/j.ajls.20140204.14

\begin{abstract}
Study was conducted to assess the histopathological damage of Gill, Liver and Brain in common carp, Cyprinus carpio after sublethal exposure to Quinalphos. Exposed to sublethal concentration (One tenth $(1 / 10$ th, $0.75 \mu \mathrm{l} / \mathrm{L})$ of commercial grade quinalphos (25\% Emulsified Concentration) for 1, 7, 14, 21 and 30 days and a parallel control was run simultaneously. Gill, Liver and Brain of exposed individuals exhibited some remarkable changes in their histology in comparison to control. Prominent changes include shrinkage of the glomerulus, and dilation of tubular lumen. Vacuolization, desquamation, hydropic swelling and hyaline degeneration of tubular epithelium is also observed. Cyst formation and hemorrhage also appear in certain specimens. Duration of exposure appears to have a profound effect on Gill, Liver and Brain as with increasing duration of exposure histopathological damages become more severe.
\end{abstract}

Keywords: Histopathology, Cyprinus Carpio, Quinalphos, Gill, Liver, Brain

\section{Introduction}

Pesticides have been widely used all over the world to control insects, pests and disease vectors. They ultimately find their way into aquatic habitats such as rivers, lakes and ponds, and have been found to be highly toxic not only to fish but also to the organisms, which constitute the food chain [1-3]. Moreover, Agriculture, as the largest consumer of freshwater and as a major cause of reduction of surface and groundwater resources through erosion and chemical runoff directly correlates with the loss of water quality [413]. Pesticides in general, are used very extensively in agriculture, forestry, public health and in veterinary practices. Hence, it is necessary to study the immediate and chronic effects of pesticides on fish, which form a part of human diet. These compounds have a tendency to accumulate in small quantities in lower fish food organisms and ultimately biomagnify in the fish species. A broadspectrum organophosphate used heavily throughout the world for agriculture and domestic purposes [14]. The frequent occurrence of organophosphate pesticides has been regarded as a serious global public health problem and a major environmental issue. To a lesser extent, they can also absorb the toxins directly from the water $[15,16]$. Therefore, it would be pertinent to study the effect of such organophosphate pesticides on long-term exposure by chronic studies to ascertain the residual toxicity.

Histopathological changes have been widely used as biomarkers in the evaluation of the health of fish exposed to contaminants, both in the laboratory $[17,18]$ and field studies [19-21]. One of the great advantages of using histopathological biomarkers in environmental monitoring 
is that this category of biomarkers allows examining specific target organs, including gills and liver that are responsible for vital functions, such as respiration, excretion and accumulation and biotransformation of xenobiotics in the fish [22], and serve as warning signs of damage to animal health [23].

Quinalphos is one of the organophosphate insecticides extensively used in agriculture in our area. The Environment Centre of National Toxicology declared that, there are a dozen highly dangerous chemicals including quinalphos. Quinalphos is a hard insecticide, which has become a matter of concern because of its potentiality and hazardous effect. The present study was performed to evaluate the sub-lethal effects of quinalphos on histopathological alterations in the vital organs like brain, gill and liver of fresh water teleost (Cyprinus Carpio) as a laboratory animal model. The Cyprinus Carpio was selected for the bioassay experiments since it is one of the most economically important freshwater fish that is extensively cultured in India, China and other countries.

\section{Materials and Methods}

Fish were collected from ponds of local government hatchery with the help of fishermen. Fishes were caught by fishing net and carefully packaged into aerated polythene bags filled with tube well water. Fishes were brought to laboratory and immediately given $0.05 \%$ potassium permanganate treatment for two minutes for disinfecting them. After disinfectant treatment they were transferred into plastic pools of $500 \mathrm{~L}$ capacity for two weeks acclimatization to laboratory conditions. Fishes were starved for first $24 \mathrm{hr}$ and then fed ad lib rice bran mixed with mustard oilcake in the ratio of $2: 1$, during acclimatization. Water of the pool was changed daily and dead fishes were removed immediately whenever located.

The experiment was conducted under natural photoperiod and temperature. Water quality was measured as per APHA [24]. The temperature of the experimental water was $23 \pm$ $1.5^{\circ} \mathrm{C}$, pH was $7.2 \pm 0.4$, Dissolved oxygen was $7.2 \pm$ $0.6 \mathrm{mgl}^{-1}$, and free carbon dioxide was $6.2 \pm 0.4 \mathrm{mgl}^{-1}$ and total hardness as calcium carbonate was $112 \pm 3.2 \mathrm{mgl}^{-1}$.

For the histological study, $0.75 \mu \mathrm{l} / \mathrm{L}$ of commercial grade quinalphos (25\% Emulsified Concentration) was selected as sub lethal concentration. Common carp individuals of size, 17-22 cm, and weight, 50-65 gm was sorted and starved for $24 \mathrm{hr}$ before starting the experiment. Six specimens were exposed to the sub lethal dose for $1,7,14$, 21 and 30 days and a control was run simultaneously.

Fish were sacrificed at 1, 7, 14, 21 and 30 days of exposure. Fish were first immobilized in ice and then dissected out carefully; Gill, Liver and Brain were removed and fixed in bouins fluid for $24 \mathrm{hr}$ and then processed and embedded in paraffin for block preparation. The sections were about 5-6 micron and stained with haematoxylin and eosin. The slides were examined under a light microscope and photographed for histopathological effects.

\section{Results}

\subsection{Gill}

PLATE-1
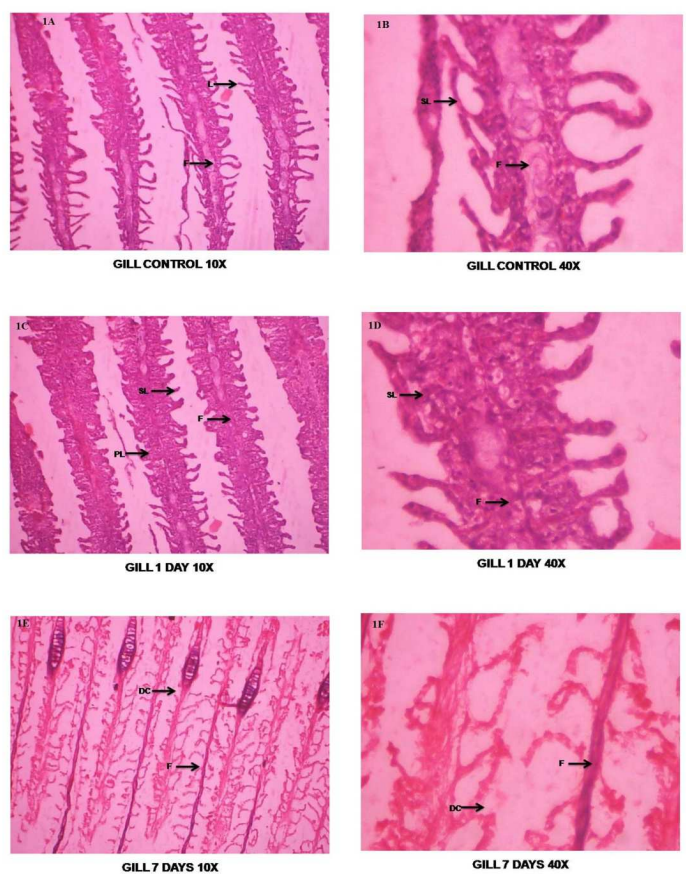

Plate 1, Figure 1. A $(10 X) \& B(40 X)$ Control fish gill, $C(10 X) \& D(40$ $X)$ experimental fish gill 1st day, $E(10 X) \& F(40 X)$ experimental fish gill 7 days, showing Lamellae (L), Filament (F), Secondary Lamella (SL), Primary Lamella $(P L)$ and Degenerative Changes $(D C)$.

\section{PLATE- 2}
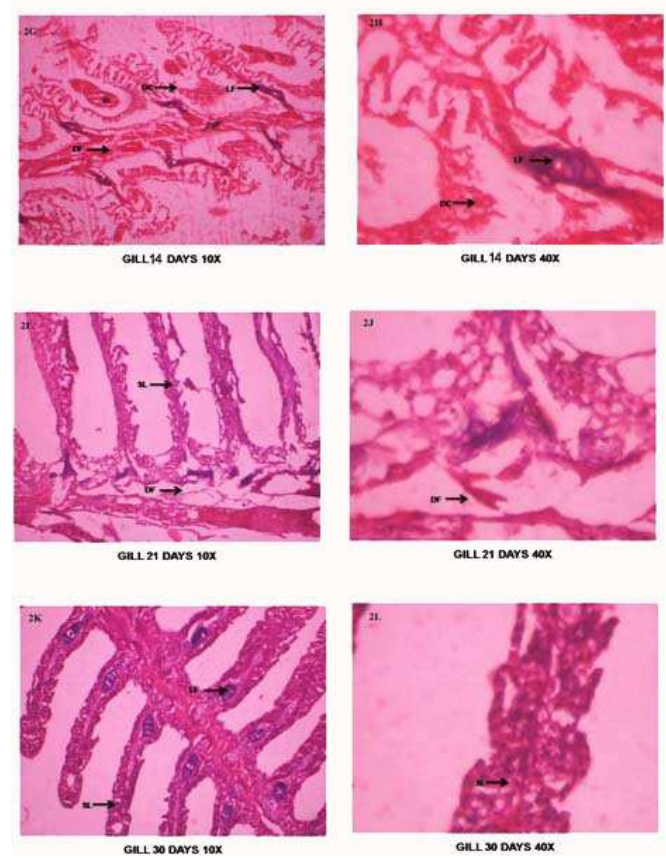

Plate 2, Figure 2. $G(10 X) \& H(40 X)$ experimental fish gill 14 days, I $(10 X) \& J(40 X)$ experimental fish gill 21 days, $K(10 X) \& L(40 X)$ experimental fish gill 30 days, showing Damage of Filament (DF), Degenerative Changes (DC), Lamellar Fusion (LF) and Secondary Lamella (SL). 
The structure of the gill of control fish consists of primary lamellae, secondary lamellae with well marked inter lamellar spaces. The gill lamella consists of respiratory epithelial cells and pilaster cells situated in between the blood capillaries. An exposure of the fish for a period of 1 day to sub lethal concentration of quinalphos showed that there were no significant pathological changes in the gills of the fish (Plate1, Fig.1c and1d). On exposure for a period of 7 days has shown some degenerative changes and lamellar fusion (Plate-1, Fig. 1e and 1f). On exposure for a period of 14 days a further damage was occurring in the gill structure. The primary and secondary gill lamellae showed heavy degenerative changes and lamellar fusion (Plate. 1, Fig.1c and 1d). Additional exposure for a period of 21days less degenerative changes were observed in the structure of the gills appeared with mild degree of degenerative changes and lamellar fusion (Plate. 2, Fig.2i and 2j). Exposure for a period of 30 days has shown very less degenerative changes (Plate. 2, Fig. 2k and 21).

\subsection{Liver}

The structure of the normal liver of the fish consists of a continuous mass of large hexagonal cells. The hepatocytes are large in size with homogenous granular cytoplasm and either centrally located distinct nuclei. Each cord separated by the thick wall of the peripheral cells (Plate. 3, Fig. 3a and $3 b$ ). No significant changes were observed in the structure of the liver of the fish exposed for a period of 1 day to the quinolphos (Plate. 3, Fig. 3c and 3d). However, in the fish after 7 days of exposure has shown necrotic changes (Plate. 3, Fig. 3e and 3f). An exposure of 14 days witnessed hepatocytes with widespread vacuoles, clear necrotic changes and picnotic nuclei of cells (Plate. 4, Fig. $4 \mathrm{~g}$ and $4 \mathrm{~h}$ ). Exposure for a period of 21 days resulted in degenerative hepatocytes, changes in central vein with congestion (Plate. 4, Fig. 4i and 4j). Only the degenerative changes were witnessed after 30 days of exposure.
PLATE-3
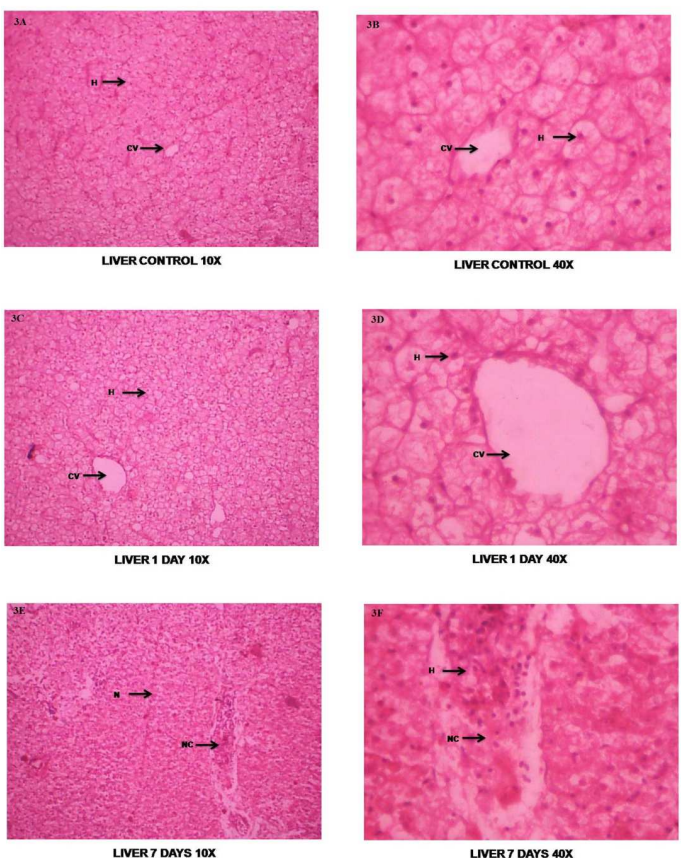

Plate 3, Figure 3. $A(10 X) \& B(40 X)$ Control fish liver, $C(10 X) \& D(40$ $X)$ experimental fish liver 1st day, $E(10 X) \& F(40 X)$ experimental fish liver 7 days, showing Hepatocytes (H), Central Vein (CV) and Necrotic Changes $(N C)$.

\section{PLATE-4}
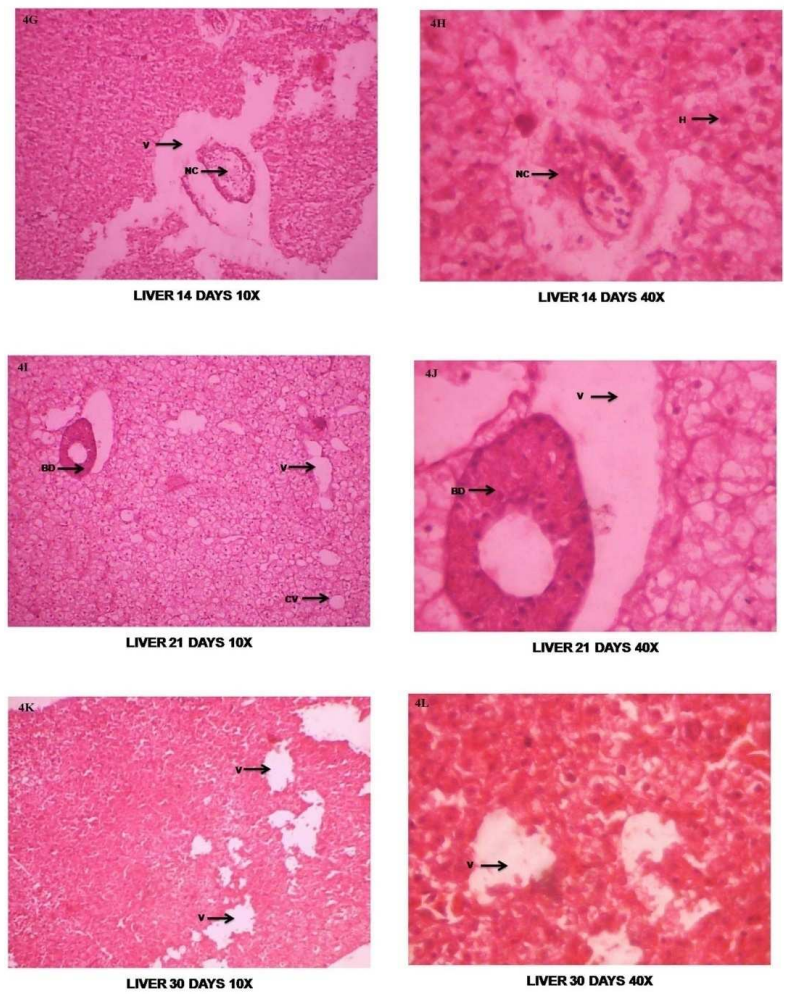

Plate 4, Figure 4. $G(10 X) \& H(40 X)$ experimental fish liver 14 days, $I$ $(10 X) \& J(40 X)$ experimental fish liver 21 days, $K(10 X) \& L(40 X)$ experimental fish liver 30 days, showing Hepatocytes $(H)$, Vacuolization $(V)$, Necrotic Changes $(N C)$ and Bile Duct (BD) 


\subsection{Brain}

The architecture of brain in the control fish showed clear neural cells with distinct nuclei (Plate. 5, Fig. 5a and 5b). On $1^{\text {st }}$ day of exposure to sub lethal toxicity of quinalphos showed mild degenerative changes in neural cells when compared to control. After 7 days of exposure period the brain tissue has shown structural damage, necrotic changes in neural cells and intracellular edema (Plate. 5, Fig. 5e and 5f). On exposure of 14 days more degenerative changes, increased necrotic condition of neural cells and cytoplasmic vacuolization observed (Plate. 6, Fig. 6g and 6h). From day 21 to day 30 showed slight degenerative changes and vacuolization (Plate. 6, Fig. 6k and 61) when compared to 14 day exposure period.

\section{PLATE - 5}

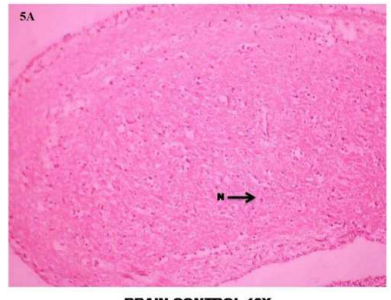

BRAIN CONIROL 10X

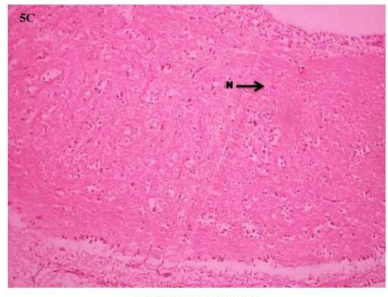

BRAIN 1 DAY 10X

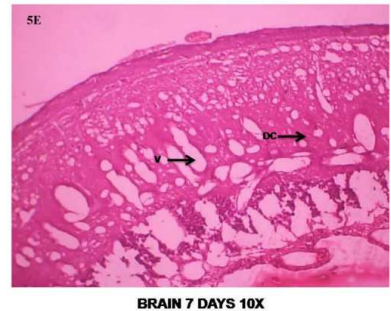

Plate 5, Figure 5. $A(10 X) \& B(40 X)$ Control fish brain, $C(10 X) \& D$ $(40 X)$ experimental fish brain 1st day, $E(10 X) \& F(40 X)$ experimental fish brain 7 days, showing Nucleus (N), Vacoulation (V) and Degenerative Changes (DC).

\section{PLATE- 6}
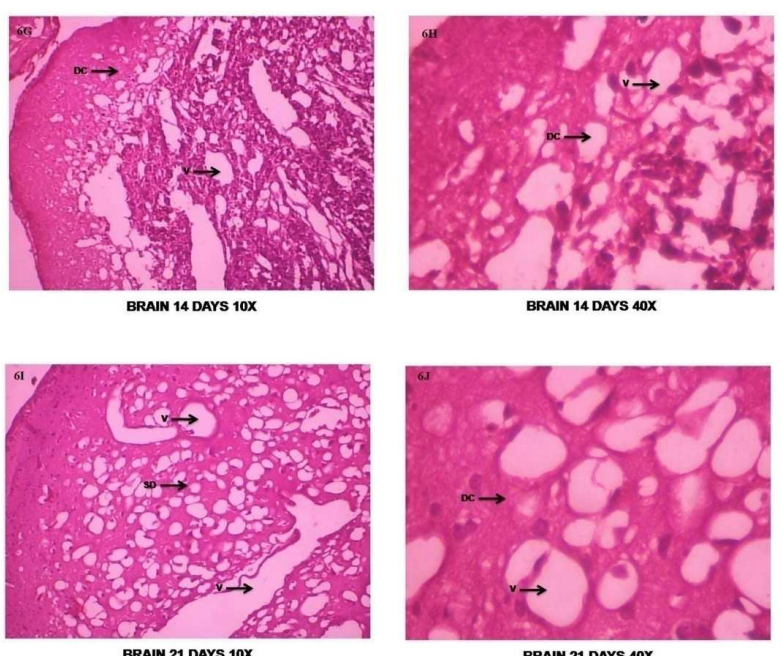

BRAIN 21 DAYS 10X
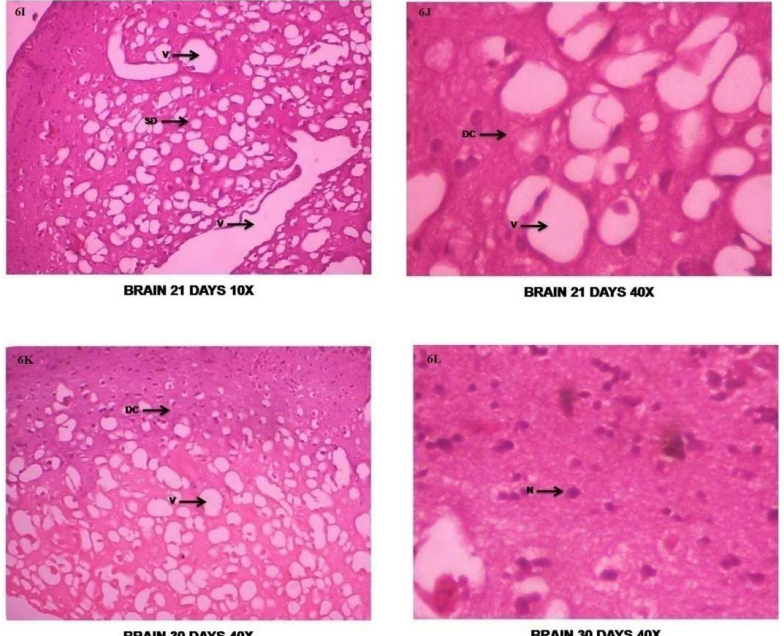

BRAIN 21 DAYS 40X

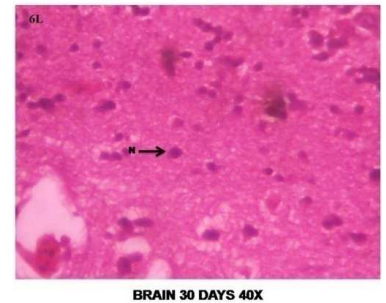

Plate 6, Figure 6. $G(10 X) \& H(40 X)$ experimental fish brain 14 days, $I$ $(10 X) \& J(40 X)$ experimental fish brain 21 days, $K(10 X) \& L(40 X)$ experimental fish brain 30 days, showing Nucleus (N), Vacoulation (V) and Degenerative Changes (DC).

\section{Discussion}

Tissue histology is considered as an indicator of exposure to pollutants, represents a useful tool to assess the degree of pollution, particularly for sublethal and chronic effects [25]. Histopathological changes in the present study were in agreement with the study recorded in the liver of fish (O. niloticus $\mathrm{L}$.) treated with lorsban and vitamin $\mathrm{E}+$ lorsban for four consecutive weeks. Hepatosomatic index of the vitamin $\mathrm{E}$ treated group were insignificant throughout the experimental periods. Few studies recorded that, the hepatosomatic index was not affected by the dietary $\alpha$-tocopherol levels. The common liver abnormalities observed in the present study were loss of parenchymal architecture, fatty degeneration, vacuolar degeneration, atrophy and necrosis of hepatic and pancreatic cells with leucocytic infiltration. The recorded results in the present study were similar to those observed by Tilak et al., and Kunjamma et al., [26, 27] recorded pyknotic nucleus, protein precipitation, pancreatic acini appeared with the loss normal structure and necrosis of the hepatic and pancreatic tissue in freshwater fish (Catla catla) and (Oreochromis mossambicus) treated with chlorpyrifos. The present results were more or less in agreement with other studies in which necrosis and lipidosis vacuolization, an increase of macrophage aggregates and eosinophilic 
granular cells were recorded in fish treated with insecticides malathion and paraquat, respectively [28, 29]. Changes in the liver were time and concentration dependent.

Histological changes in the liver could be attributed to the fact that, the liver is the major site of detoxification [30], it is expected that the toxicant insecticide would reach there in abundance for detoxification and disposal [31]. Fatty vacuolar degenerations of hepatic tissues could reflect abnormal lipid metabolism (e.g., lipid peroxidation), since lipid accumulation was prominently observed in the present study, it might be an indication of earlier liver damage [32]. While, [33] recorded that, accumulation of the lipid droplets in the hepatocyte cytoplasm could be considered as a defense mechanism. In the present study, the appearance of pycnotic nuclei indicated that the cells became hypofunctional. Focal necrosis were also observed in the liver of the fishes Heteropneustes fossilis and Brachydanio were exposed to organophosphate insecticide malathion and dimethoate 500, respectively [34]. Focal necrosis is probably due to the involvement of liver cells in the metabolic transformation of the insecticide, causing functional and structural changes to the cells [35]. Morphological changes in the liver supported many various biochemical reactions as indicated by enzyme activities [36].

Brain is the controlling center of all functions and movements in the body organisms like fish serving as a relay station. In the present study hyperplasia, edema, necrosis and an increase in brain cells were some of the histological changes observed in the brain of the fish Cyprinus carpio exposed to sub lethal concentration of quinolphos toxicity. These changes could be related to possible inhibition or decreased cholinergic activity on exposure to quinalphos. Since, quinalphos is a potent neurotoxic agent which inhibits acetyl cholinesterase activity of brain [37]. Similarly, membrane bound $\mathrm{K}^{1+}$, $\mathrm{Mg}^{1+}$ ATPase and $\mathrm{Ca}^{2+}$ ATPase activities have been decreased in dose and time depend manner in the brain regions (hen mesencephalon, cerebellum and medulla oblongata) of the fish Oreochromis mocsombicus [38], which supports the histological changes observed in the brain of Cyprinus Carpio in the present study.

Thus the histological changes that were taking place in the present study, as the initial period of exposure in the organs of the fish on exposure to quinolphos toxicity might be a part of defense mechanism. The further accumulation of quinolphos in the organs of the fish on prolonged exposure caused destruction in the organ structures. The slight structural reorganization of the gill, liver, and brain of the fish observed at day 30 of exposure to quinolphos toxicity gives support to some extent that the ability of the fish to resist the sublethal stress and in the repair of the damage caused to the organ by enhancing the protein synthetic potentials and other associated activities of the cell.

\section{Conflict of Interest}

The authors declare that we have no conflict of interest.

\section{References}

[1] Apostol S. The toxicity of certain pesticides to protozoa. Proc Symp Environ Biol 1979 : 97-102.

[2] Ghosh TK, Konar SK. Effects of sublethal levels of the insecticide aldrin on fish and fish-food organisms. Proc Symp Environ Biol 1979;103-112.

[3] Muley DY, Mane UH. Toxicity of endosulfan 35 EC to estuarine edible clam Katelysia opima (Gmelin) from west coast of India. Proc Natl Symp Environ Biol 1986;117-123.

[4] Wauchope RD. The pesticide content of surface water draining from agricultural fields. Journal of environmental quality $1978 ; 7: 459-472$.

[5] Li H, Wang Y, Shi LQ, Mi J, Song D, Pan XJ. Distribution and Fractions of Phosphorus and Nitrogen in Surface Sediments from Dianchi Lake, China. Int J Environ Res 2012; 6 (1):195-208.

[6] Ashraf MA, Maah MJ, Yusoff I. Bioaccumulation of Heavy Metals in Fish Species Collected From Former Tin Mining Catchment. Int J Environ Res 2012; 6 (1):209-218.

[7] Mhadhbi L, Boumaiza M. Toxic Effects of Acute Exposure of Diazinon in turbot (Psetta maxima) Early Life Stage (ELS). Int J Environ Res 2012; 6 (1):139-144.

[8] Strohschön R, Wiethoff K, Baier K, Lu L, Bercht AL, Wehrhahn R, Azzam R. Land use and Water Quality in Guangzhou, China: A survey of ecological and Social Vulnerability in Four Urban Units of the Rapidly Developing Megacity. Int J Environ Res 2013; 7(2):343-358.

[9] Tajziehchi S, Monavari SM, Karbassi AR, Shariat SM, Khorasani N, Quantification of Social Impacts of Large Hydropower Dams- a case study of Alborz Dam in Mazandaran Province. Northern Iran Int $\mathrm{J}$ Environ Res 2013;7 (2):377-382.

[10] García-Flores E, Wakida FT, Espinoza-Gomez JH. Sources of Polycyclic Aromatic Hydrocarbons in Urban Storm Water runoff in Tijuana, Mexico. Int J Environ Res 2013; 7(2):387-394.

[11] Etale A, Drake DC. Industrial Pollution and Food Safety in Kigali, Rwanda. Int J Environ Res 2013; 7(2):403-406.

[12] Ghaderi AA, Abduli MA, Karbassi AR, Nasrabadi T, Khajeh M. Evaluating the Effects of Fertilizers on Bioavailable Metallic Pollution of soils, Case study of Sistan farms, Iran. Int J Environ Res 2012; 6(2):565-570.

[13] Miletić Z, Knežević M, Stajić S, Košanin O, Đorđević I. Effect of European Black Alder Monocultures on the Characteristics of Reclaimed Mine Soil. Int J Environ Res 2012; 6(3):703-710.

[14] Ali D, Nagpurea N, Kumar S, Kumar R, Kushwahaa B, Lakraa W. Assessment of genotoxic and mutagenic effects of chlorpyrifos in freshwater fish Channa punctatus (Bloch) using micronucleus assay and alkaline single-cell gel electrophoresis. Food Chem Toxicol 2009; 47: 650-656.

[15] Phillips MJ, Roberts RJ, Stewart JA, Codd GA. The toxicity of the cyanobacterium Microcystis aeruginosa to rainbow trout, Salmo gairdneri Richardson. J Fish Dis 1985; 8:339-344. 
[16] Smith JL, Boyer GL, Zimba PV. A review of cyanobacterial odours and bioactive metabolites: impacts and management alternatives in aquaculture. Aquaculture 2008; 280:5-20.

[17] Wester PW, Canton JH.. The usefulness of histopathology in aquatic toxicity studies. Comp Biochem Physiol 1991; 100:115-117.

[18] Thophon S, Kruatrachue M, Upathan ES, Pokethitiyook P, Sahaphong S, Jarikhuan S. Histopathological alterations of white seabass, Lates calcarifer in acute and subchronic cadmium exposure. Environmental Pollution 2003;121: 307320 .

[19] Hinton DE, Baumann PC, Gardner GR, Hawkins WE, Hendricks JD, Hoque RA, M. J. A. Mirja MM, Miah MS. Toxicity of Diazinon and Sumithion to Puntius gonionotus. Bangladesh J Tran Dev1993; 6(1):19-26.

[20] Schwaiger J, Wanke R, Adam S, Pawert M, Honnen W, Triebskorn R. The use of histopatological indicators to evaluate contaminant-related stress in fish. J Aquatic Ecosystem Stress and Recovery 1997; 6:75-86.

[21] Teh SJ, Adams SM, Hinton DE. Histopathological biomarkers in feral freshwater fish populations exposed to different types of contaminant stress. Aquatic Toxicology 1997; 37:51-70.

[22] Gernhofer M, Pawet M, Schramm M, Müller E, Triebskorn R. Ultrastructural biomarkers as tools to characterize the health status of fish in contaminated streams. J Aquatic Ecosystem Stress and Recovery 2001; 8:241-260.

[23] Hinton DE, Laurén DJ. Liver structural alterations accompanying chronic toxicity in fishes: potentioal biomarkers of exposure. In: McCarthy, J. F. and L. R. Shugart (Eds.). Biomarkersof Environmental Contamination. Boca Raton, Lewis Publishers. Pp. 51-65: 1993.

[24] APHA. Standard methods for examination of water and wastewater, 21st Edn. [AWWA, WPCF, Washington DC, USA; 2005].

[25] Cengiz E, Ünlü E. Histopathology of gills in mosquitofish, Gambusia affinis after long-term exposure to sub-lethal concentrations of malathion. J Environ Sci Healt B 2003; 38(5):581-589.

[26] Tilak K, Rao K, Veeraiah K. Effects of Chlorpyrifos on histopathology of the fish Catla catla. J Ecotoxicol Environ Monit 2005; 15 (2):127-140.

[27] Kunjamma A, Philip B, Bhanu S, Jose J. Histopathological effects on Oreochromis mossambicus (Tilapia) exposed to chlorpyrifos. J E R D 2008; 2(4):553-559.
[28] Figueiredo-Fernandes A, Fontainhas-Fernandes RE, ReisHenriques MA. Effects of Paraquat on Hepatic EROD activity, liver and gonadal Histology in male and female Nile Tilapia, Oreochromis niloticus exposed to different temperatures. Arch Environ Contam Toxicol 2006); 51(4):626-632.

[29] Elezaby M, El-Serafy S, Heckmann R, Sharf-Eldeen K, Seddek M. Effect of some toxicants on the fresh water fish Oreochromis niloticus. J Egypt Ger Soc Zool 2001; 36:407344.

[30] Nagai T, Yukimoto T, Suzuki N. Glutathione peroxidase from the liver of Japanese sea bass Laeolabrax japonicus. Z Naturforscher 2002; 57C:172-176.

[31] Mushigeri SB, David M. Fenvalerate induced changes in the Ach and associated AChE activity in different tissues of fish Cirrhinus mrigala (Hamilton) under lethal and sub-lethal exposure period. Environmental Toxicology and Pharmacology 2005; 20:65-72.

[32] Anthony J, Banister E, Oloffs P. Effect of sub-lethal levels of diazinon: Histopathology of Liver. Bull Environ Contam Toxicol 1986; 37:501-507.

[33] Al-Jahdali MO, Bin Bisher AS, Abu zeid IM, Physiological and histological alterations in rats liver induced by Sumithion ${ }^{\circledR}$ an insecticide used in dengue fever vector control in Jeddah. Saudi Arabia. Saudi J Biol Sci 2007; $14(1): 43-51$.

[34] Rodrigues E, Fanta E. Liver histopathology of the fish Brachydanio rerio Hamilton-Buchanan after acute exposure to sub-lethal levels of organophosphate dimetoato 500 . Rev Bras Zool 1998; 15(2):441-450.

[35] De Melo G, Donattib L, Rudnikia C, Fanta E. Hepatic alterations in the fish Rhamdia quelen contaminated with Folidol 600®. Ecotoxicol Environ Saf 2008; 71:821-829.

[36] Gül S, Belge-Kurutaș E, Sahan A, Doran F. Pollution correlated modifications of liver antioxidant systems and histopathology of fish (Cyprinidae) living in Seyhan Dam Lake, Turkey. Environ Int 2004; 30(5):605-609.

[37] Anam KK, Maitra SK. Impact of quinalphos on blood glucose and acetylcholinesterase (AChE) activity in brain and pancreas in a roseringed parakeet (Psittacula krameri borealis:Newmann). Archives of Environmental Contamination and Toxicology 1995; 29(1):20-23.

[38] Durairaj S. Quinalphos, phenthoate and their combined effect on brain ATPases of fish Oreochromis mossambicus. Pollution Research Paper (EM International) 2001; 20(1):139-142. 